Experiments were made with the object of testing whether the friction between the wall and the backing was of importance, and these showed that this friction did not affect the horizontal thrust.

The second paper, by Mr. Angus Robertson Fuiton, gives an account of experiments made on the overturning moments on retaining walls. The method of direct measurement of the moment was employed; the filling was of three kinds:-(I) clean river sand, (2) gravel, and (3) garden soil. The total height without surcharge was limited to $7 \mathrm{ft}$., and with surcharge it reached $9 \mathrm{ft}$. The experiments without surcharge show that results calculated from the Rankine theory are greatly in excess of the observed values, while those obtained from the wedge theory approximate fairly closely to experiment. For surcharged vertical walls with unlimited slope the wedge and Rankine formulæ give values too great by 20 and 50 per cent. respectively. In the whole series of experiments the greatest discrepancy occurred with the 7 -ft. levels (no surcharge) when gravel-filling was used, and was worst with the wall inclined outward. Low experimental values were also obtained in the sand tests at the lower level under surcharge. $\mathrm{Mr}$. Fulton concludes that the wedge theory gives good results with material uncompacted for walls in which the inclination of the inner face is not greater than usually obtains in practice.

\section{Fellowship of the New Zealand Institute.}

$A^{T}$ the annual meeting in I9I9 of the Board of A Governors of the New Zealand Institute it was decided to establish a fellowship of the institute, since -apart from Hutton and Hector memorial medals, which can be gained only by very few-there are no honours attainable in the Dominion for those engaged in scientific research, the number of whom has greatly increased in recent years, while more branches of science are pursued than formerly. This fellowship, which entitles the recipient to place the letters "F.N.Z.Inst." after his name, is limited to forty fellows, and not more than four are henceforth to be elected in any one year until the number is complete, after which only such vacancies as occur may be filled.

In order to make a commencement, and as there were many who well deserved recognition for their long and valuable services to science, it was resolved that, in the first place, twenty original fellows should be appointed, these to consist of the living past-presidents, together with Hutton and Hector medallists (ten in all), and of ten more members of the institute who were to be elected by the past-presidents and medallists from persons nominated by the various affiliated branches of the institute.

The fellowship is to be given only for research or distinction in science, and it is plain that the distinction even now is far from easy of attainment, and that, as time goes on, its value will greatly increase. The election and appointment of the original fellows took place at the close of IOIO, and resislted as follows :-Mr. B. C. Aston, *łProf. W. B. Benham, + Mr. Elsdon Best, *+Mr. T. F. Cheeseman, *+Prof. Chas. Chilton, *+1Dr. L. Cockavne, +Prof. T. H. Easterfield, Prof. C. C. Farr, Mr. G. Hogben. Mr. G. V. Hudson, Prof. H. B. Kirk, ttDr. P. Marshall, * Dr. D. Petrie, +Sir Ernest Rutherford. Prof. H. W' Segar, Mr. S. Percy Smith, Mr. R. Speight, Prof. A. P. W. Thomas, *the Hon. G. M. Thomson, and Dr. J. Allan Thomson. * signifies past-president; + Hector medallist; and I Hutton medallist. NO. 2629 , VOL. IO5]

\section{The Proposed University of Reading.}

I ORD HALDANE'S conception of the division of the country into areas in each of which a "civic education scheme is but also essential. In Georgian and Victorian days a university was looked upon as primarily an institution for the completion of the teaching work of public schools. The wider view is taken now of the university as a focus of the intellectual life of the community which it serves and as a centre for research.

When in 1902 it was proposed that the Victoria University should be split up into the Universities of Manchester and Liverpool, many regarded the multiplication of degree-giving bodies with apprehension. It was feared that it would lead to a competition downwards. The reverse of this has happened. Leeds, Sheffield, and Bristol have secured independent universities, and each of them fears, above all things, the imputation that its degrees are less desirable than those of any other.

Reading is now seeking a charter. This project is not new. In I9II the college received great endowments from Mr. and Mrs. G. W. Palmer, Lady Wantage, and Mr. Alfred Palmer, given for the purpose of enabling it to qualify for a charter. The scheme was interrupted by the war, but has now been taken up again with the utmost vigour. Three or four only of our modern universities have so large a permanent source of income. Its students are now more numerous than were those of two chartered English universities before the war.

In the provision of residential accommodation Reading is unique. Its six hostels lodge upwards of four hundred students. The college has also certain definite claims to be regarded as a national institution. In addition to the faculties of letters and science and the departments of fine arts, music, and domestic subjects, its distinctive line of study is agriculture, horticulture, and dairying. In these subjects it is a most important centre of research. Students go to it, not only from the whole of the United Kingdom, but also from the Continent and the British Dominions overseas.

The desire for independence is most natural. As matters stand at present, its professors and lecturers have no voice in determining the conditions for degrees, in settling the syllabuses of teaching, in carrving out the examinations, or in marking their students' answer-papers.

\section{University and Educational Intelligence.}

CaMbridge.--Prof. Horace Lamb, Sir Thomas L. Heath, Prof. W. H. Bragg, and Dr. Henry Head have been elected honorary fellows of Trinity College.

Mr. A. Amos, Downing College, has been appointed University lecturer in agriculture, and $\mathrm{Mr}$. G. U. Yule, St. John's College, re-appointed University lecturer in statistics.

A Smith's prize has been awarded to S. Pollard, fellow of Trinity College, for an essav on "The Stieltjes Integral and its Generalisations."

The following grants have been made from the Gordon-Wigan fund:- $5 \mathrm{ol}$. for plant-breeding experiments. 5ol. for an experimental gas chamber in the physiological laboratory, $50 l$. to assist in the provision and displav of entomological specimens, 3ol. to help in the study of Pleistocene deposits round Cambridge, and $5 o l$. towards a deficit on the working of the botanical department. 